\title{
A importância do Estado laico e da inspiração religiosa na construção da justiça: considerações de Paul Ricoeur
}

\author{
Ceci Maria Costa Baptista Mariani* \\ Robison Moreli Amadeu** \\ Walter Ferreira Salles***
}

\section{RESUMO}

Em diversas ocasiões, Ricoeur afirma que o conceito de justiça pode ser pensado mediante o desígnio de uma vida boa, com e para o outros, em instituições justas. Desta máxima, procedem os predicados bom (teleologia) e legal (deontologia). A construção da justiça, sendo assim, depende não só de mecanismos institucionais, mas também da íntima convicção oriunda da sabedoria prática de cada sujeito que leva à boa deliberação em situações contingentes e o dado religioso é uma das fontes de inspiração dos indivíduos nas suas escolhas. Tendo isso em vista, essa pesquisa tem como objetivo empreender uma reflexão sobre o papel da religião nas esferas da justiça a partir do diálogo entre a tradição cristã e a contemporânea sociedade secular.

Palavras-chave: Justiça. Teleologia. Deontologia. Religião. Estado de Direito.

* Doutora em Ciências da Religião pela Pontifícia Universidade Católica de São Paulo. Membro do corpo docente permanente do PPG em Ciências da Religião da PUC-Campinas. São Paulo-SP, Brasil. Contato: cecibmariani@gmail.com. Indicação para o Currículo Lattes: http://buscatextual.cnpq.br/buscatextual/visualizacv.do?id=K4737272Y1

** Bacharel em Filosofia pela Pontifícia Universidade Católica de Campinas/SP e graduando em Teologia da mesma universidade. Indicação para o Currículo Lattes: http://lattes.cnpq. br/7334881590551294

*** Doutor em Ciências da Religião pela Universidade Metodista de São Paulo. Membro do corpo docente permanente do PPG em Ciências da Religião da PUC-Campinas. São Paulo-SP, Brasil. Indicação para o Currículo Lattes: http://buscatextual.cnpq.br/buscatextual/visualizacv.do?id=K4704461J5 


\title{
THE IMPORTANCE OF LAY STATE AND RELIGIOUS INSPI- RATION FOR THE CONSTRUCTION OF JUSTICE: CONSIDE- RATIONS ON PAUL RICOEUR
}

\begin{abstract}
Paul Ricoeur often affirms the concept of justice can be thought aiming at the good life with and for others, in just institutions. From this perspective some predicates, such as, the good (teleology) and the legal (deontology), are proceeded. Therefore, the construction of justice not only depends on an institutional mechanisms, but also it depends on the intimate conviction from the practical wisdom of each subject that leads to good deliberation in contingent situations. Also, religion, for itself, is one of the inspiration sources for individuals choices. For this research reflects on religion role in the spheres of justice considering the dialogue between Christian tradition and contemporary secular society.
\end{abstract}

Keywords: Justice. Teleology. Deontology. Religion. Rule of law.

\section{INTRODUÇÃO}

Paul Ricoeur apresenta uma preocupação de longa data com o tema da justiça, talvez pelo seu conturbado contexto histórico que engloba duas guerras mundiais e a guerra fria. Em 1991, ele tratou desta questão numa conferência intitulada $O$ justo entre o legal e o bom, na qual refletiu sobre a tensão entre as abordagens teleológica (vida boa) e deontológica (lei) na determinação da ideia de justiça a partir de sua visada ética que abrange " $a$ visada da 'vida boa' com e para outrem em instituições justas" (RICOEUR, 2014, p. 186, grifo do autor).

Resumidamente, a questão da justiça estaria fundamentada numa dialética entre uma concepção teleológica, enraizada no pensamento aristotélico a partir do desejo da vida boa e uma concepção deontológica sob o impulso do pensamento kantiano que coloca a justiça sob a ótica da lei e da legalidade. Na primeira, a justiça seria concebida como uma virtude que orientaria a ação humana para uma vida realizada ou eudaimonia. Neste sentido, a justiça seria a finalidade da ação humana e, como telos, apresentar-se-ia como um fim jamais alcançado de forma plena, porém, buscado continuamente na concretude da vida. $\mathrm{O}$ 
bom designaria o telos de uma vida em busca da realização com e para os outros em instituições justas. Entretanto, como o predicado bom é marcado pela incerteza e falta de consenso, a realização de uma vida feliz (eudaimonia) exigiria uma segunda visão, a deontológica, que apontaria para a necessidade de se evitar o mal, seja pela imputação ou pela obrigatoriedade. A justiça seria vista, assim sendo, mais como meio do que como fim, e é pensada a partir da noção de contrato como foi apresentada por Kant e retomada no século XX por John Rawls (1921-2002).

Deste modo, Ricoeur faz um esforço para jamais separar o aspecto teleológico da justiça de seu aspecto deontológico e o justo se qualificaria de acordo com as decisões tomadas em clima de conflito e incerteza orientadas pela noção de fim e balizadas pelas normas. Por conseguinte, o percurso da justiça seria feito sobre os traços do querer viver bem com e para os outros, da aplicação das normas a partir das instituições justas e da íntima convicção oriunda da sabedoria prática tendo em vista a boa deliberação em situações contingentes, exercida no trágico da ação. É justamente esta abordagem que nos ajudará a pensar a importância do Estado laico e da religião na construção da justiça.

\section{VIDA BOA COM E PARA OS OUTROS EM INSTITUIÇÕES JUSTAS}

Os predicados bom e obrigatório são aplicados às ações e aos agentes e, neste horizonte, em que se ressalta a conduta, é muito comum a utilização dos termos ética e moral com seus variados sentidos. Ricoeur toma a iniciativa de dar a esses conceitos uma nova roupagem distinguindo-os, mesmo que na etimologia destas palavras não haja nada que justifique tal atitude, uma vez que ambas remetem à ideia de costume (ethos, para os gregos e moralia para os latinos).

O filósofo, porém, convencionou denominar ética a visada de uma vida boa e realizada, e moral a articulação desta intenção em normas universais: "[...] é por convenção que reservarei o termo ética para a visada de uma vida plena e o termo moral para a articulação dessa visada com normas caracterizadas pela pretensão à universalidade e pelo efeito 
de coerção" (RICOEUR, 2014, p. 184). Com base nesta especificação, Ricoeur acrescenta ainda algumas hipóteses que nortearão sua teoria:

[...] à visada ética corresponderá o que chamaremos a partir de agora estima a si mesmo ${ }^{1}$ e ao momento deontológico, respeito a si mesmo ${ }^{2}$. Segundo a tese proposta aqui, deveria ficar claro: 1) que a estima a si mesmo é mais fundamental que o respeito a si mesmo; 2) que o respeito a si mesmo é o aspecto assumido pela estima a si sob o regime da norma; 3) que as aporias do dever criam situações em que a estima a si mesmo não aparece apenas como fonte, mas como recurso do respeito, quando nenhuma norma certa oferece mais guia seguro para o exercício hic et nunc do respeito (RICOEUR, 2014, p. 185, grifo do autor).

Para facilitar o desenvolvimento deste trabalho, a visada ética ricoeuriana será apresentada em cinco momentos e dois blocos. No primeiro bloco será abordada a perspectiva ética em três etapas: primeiramente será explicitada a concepção de vida boa, posteriormente como essa vida boa só pode ser alcançada mediante a presença do outro (com e para o outro) e, por fim, a importância das instituições justas para a concretização deste projeto. O segundo bloco submeterá a perspectiva acima à prova da norma em duas etapas: inicialmente a relação entre vida boa e obrigação e a vinculação entre solicitude e norma para, enfim, ser apresentado o encadeamento do senso de justiça aos princípios de justiça.

\subsection{VISAR À VIDA BOA}

Em consonância com Aristóteles, Ricoeur assinala: "seja qual for a imagem que cada um tenha de uma vida plena, esse coroamento é o fim último de sua ação" (2014, p. 187). A concepção de vida boa, assim sendo, mesmo que varie entre os indivíduos, se constitui como uma espécie de ideia limite que norteia as escolhas e ações do ser

A estima de si é o momento reflexivo da práxis em que o sujeito atribui à sua ação a qualidade de boa ou má.

2 O respeito de si é a estima de si no âmbito da norma, ou seja, é a reflexão da práxis e a consequente atribuição pelo sujeito às suas ações a natureza de legal ou ilegal tendo em vista as leis prescritas pelo Estado de direito. Este horizonte é importante porque garante a todos o essencial, a saber, o respeito e a dignidade. Além disso, dá margem para caracterizar o ser humano como sujeito de imputação, uma vez que este é capaz de na liberdade tomar decisões e de se responsabilizar por elas. 
humano. O lugar filosófico desta, portanto, é a práxis e a teleologia imanente à práxis é identificada como princípio estruturador da intenção ética. Cria-se, deste modo, planos de vida, isto é, o sujeito estabelece critérios e caminhos cujo cumprimento possibilita que ele obtenha a vida realizada que sonha.

Nesta perspectiva, o filósofo francês dialoga com o pensador norte-americano MacIntyre a partir de sua teoria sobre os padrões de excelência: "Esses padrões de excelência são regras de comparação aplicadas a resultados diferentes, em função de ideais de perfeição comuns a certa coletividade de executantes, interiorizados pelos mestres e pelos virtuosos da prática considerada" (RICOEUR, 2014, p. 192).

É a partir deles que se permite chamar de bom um médico ou um cantor. Entretanto, para que isso ocorra, é necessário que o profissional desenvolva bens internos próprios de sua prática a fim de se aproximar da perfeição. Por exemplo, de um bom leitor se exige a habilidade de interpretar textos. Por sua vez, esse bem interno será precioso para o plano de vida do indivíduo e constantemente ele irá avaliar suas aptidões a fim de que possa melhorar e se aproximar de seu sonho ou de seu desejo e, consequentemente, atingir a vida boa.

Este horizonte se aplica também à vida do si como um todo: "o horizonte da 'vida boa' motiva um trabalho ininterrupto de interpretação da ação do si-mesmo, em vista da melhor adequação entre aquilo que é considerado o melhor para a vida como um todo e as escolhas preferenciais que orientam e constituem a prática cotidiana" (PADILHA, 2012, p. 10). Forma-se, então, um círculo hermenêutico que oscila entre o ideal de vida boa e as escolhas fundamentais para sua concretização. Ademais, conclui-se que interpretar a ação é interpretar a si mesmo o que Ricoeur denomina no plano ético de estima de si.

Tal concepção não pode estar desligada da noção de sujeito capaz. Sendo assim, o si, autor de suas ações e responsável pelos seus atos, deve trabalhar seu interior de modo a desenvolver e hierarquizar os valores a fim de convictamente julgar bem e agir bem em busca do viver bem. 


\section{2 ...COM E PARA OS OUTROS}

É possível se questionar, levando em conta o tópico anterior, se a presença do outro é necessária para se alcançar uma vida boa. Teria Ricoeur caído na ameaça solipsista?

Sou esse ser que pode avaliar suas ações e, estimando bons os objetivos de algumas delas, é capaz de avaliar-se, estimar-se bom. O discurso do 'eu posso' é sem dúvida um discurso em eu. Mas a tônica principal deve ser posta no verbo, no poder-fazer, ao qual corresponde no plano ético o poder-julgar. A questão é então saber se a mediação do outro não é necessária no trajeto da capacidade à efetivação (RICOEUR, 2014, p. 198).

A estima de si pressupõe a alteridade de modo que o outro tem um papel fundamental na busca da vida realizada. Para aprofundar tal questão, Ricoeur recorre ao tratado aristotélico sobre a amizade oferecido nos livros VIII e IX da Ética a Nicômaco: A exploração do texto aristotélico se dá por conta de três razões: "Em primeiro lugar, já para Aristóteles, a amizade garantia a transição entre visada da 'vida boa', aparentemente centrada em sua solidão por causa da reflexividade intrínseca à estima de si, e a justiça, uma virtude de caráter plural e político" (PADILHA, 2014, p. 12).

Aristóteles defende que a amizade presume essencialmente mutualidade e reciprocidade. "Segundo a ideia de mutualidade, cada um ama o outro pelo que ele é" (RICOEUR, 2014, p. 201) e dá ao outro aquilo que recebe dele. Porém, isso exige a terceira via que é a da philautia, isto é, o amor a si mesmo. Sendo assim, o plano ético da amizade está pautado numa relação de igualdade. Analogamente, a justiça deseja essa mesma vinculação. Todavia, é preciso não confundir amizade e justiça.

A amizade está restrita às relações interpessoais, enquanto a justiça regula as relações mediadas pelo plano das instituições. Além disso, o círculo de amigos é reduzido ao passo que a justiça deve abarcar numerosos cidadãos. E, ainda, na justiça a igualdade é proporcional, levando-se em conta a desigualdade das contribuições. A igualdade nas instituições, deste modo, é uma meta, enquanto na amizade a igualdade é pressuposta (RICOEUR, 2014, p. 202).

Isto posto, o homem precisa de amigos para ser feliz? Ricoeur, tomando como base Aristóteles, argumenta que, analisando a estrutura 
do sujeito e percebendo que este é um ser carente e com necessidades, o sujeito precisa do outro si, do amigo, para que este o ajude a alcançar o que é incapaz de fazer por si só. A amizade, por conseguinte, garante estabilidade diante da falta e isto assegura que o indivíduo alcance a vida boa que tanto sonha. Tendo consciência de tal circunstância, o homem tem necessidade de amigos para ser feliz.

Nesta permuta entre dar e receber própria da amizade, em cuja essência presume reciprocidade, e na característica relevante do outro como insubstituível na estima de si revelada pela solicitude ${ }^{3}$, chega-se à conclusão de que o outro é também um ser de iniciativa capaz de hierarquizar seus valores e agir conforme sua própria estima. Ele é um si mesmo. E a vida boa só é concretizada com e para os outros, na cooperação mútua. Neste ponto, faz-se importante inserir o papel da instituição na construção de uma sociedade justa aos moldes da amizade.

\section{3 ...NAS instituições Justas}

Duas premissas são significativas para o início da discussão: “[...] o bem viver não se limita às relações interpessoais, mas estende-se à vida das instituições. De acordo com a segunda, a justiça apresenta características éticas que não estão contidas na solicitude, a saber, essencialmente a exigência de igualdade" (RICOEUR, 2014, p. 214).

Como já foi abordado acima, a vida na instituição ultrapassa a simples relação face-a-face entre o si e o outro. Além destes, existe o terceiro, o anônimo, que, apesar de não ser notado, é um membro da sociedade e, por ser constituído em dignidade, merece receber aquilo que lhe é devido para que consiga viver justamente. Eis a máxima: a cada um a sua parte, o seu direito.

Ricoeur define instituição como "[...] a estrutura do viver junto de uma comunidade histórica - povo, nação, região etc. -, estrutura irredutível às relações interpessoais [...]. A ideia de instituição caracteriza-se fundamentalmente por usos e costumes comuns, e não por regras coercitivas" (2014, p. 215). É deste ethos que a ética recebe seu nome. Esta definição enfatiza a sobreposição desta sobre qualquer tentativa de

3 Solicitude para Ricoeur designa a insubstituibilidade de cada pessoa na estima de si, tendo em vista que cada um exerce um papel único em sua história. Essa percepção torna o sujeito responsável pelo bem e pela dignidade do outro (alteridade). 
positivação da lei. Trata-se, portanto, do poder-em-comum da sociedade que emana do querer viver junto.

Tal asserção implica a retomada por Ricoeur dos conceitos arendtianos de pluralidade e acordo: "Com a ideia de pluralidade sugere-se a extensão das relações inter-humanas a todos aqueles que, como terceiros, ficam fora do face a face entre o 'eu' e o 'tu'. Mas já de saída o terceiro é, sem jogo de palavras, terceiro incluído pela pluralidade constitutiva do poder" (RICOEUR, 2014, p. 216, grifo do autor). O acordo, por sua vez, diz respeito às diversas relações existentes numa sociedade em que cada um expressa sua história e fraquezas e conta com o outro para alcançar a vida realizada.

Estas duas dimensões apontam para o terceiro elemento da visada ética, a justiça. Esta é concebida por Ricoeur de duas maneiras. Primeiramente a justiça é definida pela operação distributiva das funções políticas, riquezas, honras, vantagens etc. Neste caso, "a função das instituições é regular a distribuição dos papéis e das riquezas, assegurando a coesão entre os três componentes da perspectiva ética: o indivíduo, as relações interpessoais e a sociedade" (TURA, 2002, p. 170).

A segunda espécie de justiça se dá pelo estabelecimento da igualdade na sociedade através da reparação. Por diversos motivos a distribuição pode privilegiar alguns em detrimento de outros. Deste modo, é preciso refazê-la de modo proporcional, ou seja, os que possuem mais colaboram mais e os que detêm menos, colaboram menos. O objetivo de Ricoeur, no entanto, não é o igualitarismo, mas uma sociedade justa fundamentada na igualdade que provém da solicitude, mas que assume dimensões para além das relações interpessoais:

A igualdade, seja qual for a maneira como a modulemos, está para a vida nas instituições como a solicitude está para as relações interpessoais [...]. Assim, o senso de justiça não suprime nada da solicitude; ela a pressupõe, uma vez que considera que as pessoas são insubstituíveis. Em contrapartida, a justiça soma à solicitude, uma vez que o campo da aplicação da igualdade é a humanidade inteira (RICOEUR, 2014, p. 224-225, grifo do autor).

Tendo em conta a abordagem ricoeuriana sobre a perspectiva ética do bom, o passo seguinte nos conduzirá à reflexão sobre a sujeição des- 
sa perspectiva à norma. $\mathrm{O}$ respeito de si é a estima de si sob o regime da lei moral. Deste modo, neste horizonte deontológico, será adotada a estrutura triádica já utilizada da vida boa com e para os outros em instituições justas.

\subsection{A VIDA bOA, A ObRigaÇÃo, A SOLICITUdE E A NORMA}

$\mathrm{Na}$ busca pela vida realizada, a obrigação moral acompanha uma reivindicação de universalidade. Isso fica evidente quando se tem contato com o formalismo kantiano. Não são estabelecidos conteúdos para a ação, mas apenas critérios aos quais as máximas desta devem ser submetidas para que ela seja considerada moralmente boa: “[...] a máxima tem de ser universalizável, deve valer para todo e qualquer homem, em toda e qualquer circunstância, sem consideração pelas consequências advindas da ação" (PADILHA, 2012, p. 32).

Ricoeur argumenta que, neste estágio, qualquer ligação com a vida empírica é exaurida. Sentimentos, desejos, felicidade e prazer não adentram nesta análise, pois não atendem aos critérios de universalização. Deste modo, o desejo pela vida boa é substituído pela vontade boa. O critério ético indicava a necessidade de exercitar habilidades interiores para chegar à vida realizada. Em contrapartida, o critério moral se relaciona com a lei e é expresso pela pergunta: "que devo fazer?".

A liberdade kantiana enquanto autonomia deve ser autolegisladora, isto é, tem a obrigação de designar a vontade e as ações concretas no imperativo categórico: "Age unicamente de acordo com a máxima que te faça querer ao mesmo tempo que ela se torne uma lei universal" (KANT apud RICOEUR, 2014, p. 233). Ao obedecer esta lei prescrita por si mesmo, o homem age como autônomo.

Entretanto, este imperativo está totalmente isento de conteúdo moral. Por isso, Kant introduziu um segundo imperativo categórico que é equivalente à solicitude vigente na perspectiva ética. Tal medida foi tomada para conferir matéria à forma antes vazia: "A progressão, diz Kant, é feita a partir da 'forma, que consiste na universalidade', para a 'matéria', em que as pessoas são apreendidas como fins em si mesmas, e daí à 'determinação completa de todas as máximas', com a noção de reino dos fins" (RICOEUR, 2014, p. 237, grifo do autor). 
Aqui cabe um adendo importante para a continuidade da análise. $\mathrm{O}$ fato de Kant mencionar a necessidade de tratar as pessoas como fins pressupõe a vigência da exploração e da violência em sua época. Um sujeito está exercendo poder sobre o outro. Isso é consequência da presença do mal nas interações, desvios da solicitude. Diante disso, são indispensáveis as prescrições e proibições, expressões morais da ética: "Visto que há mal, a visada da 'vida boa' precisa assumir a prova da obrigação moral" (RICOEUR, 2014, p. 246). E a solicitude ganha caráter proibitivo.

Seria importante realizar uma mudança estrutural a ponto de transformar o poder que gera violência política, tortura, homicídios e faz do paciente uma coisa, em poder-em-comum que institui o querer viver junto.

Segundo Ricoeur, Kant nada mais fez que racionalizar a chamada Regra de Ouro, uma vez que ele exprime uma norma de reciprocidade pedindo que não se faça para o outro aquilo que não se quer que seja feito a si. Obviamente isso foi efetuado com a intenção de eliminar o caráter teleológico da Regra de Ouro, mas Ricoeur reconhece a primazia da ética. A forma positiva deste preceito aproxima-se, segundo o autor, do tu amarás teu próximo como a ti mesmo, encontrada em Levítico 19,18 e Mateus 22,39.

À vista disso, cabe agora propor uma regra de justiça alicerçada em um senso de justiça, ou, ainda, associada tanto à perspectiva ética (fim) quanto à deontológica.

\subsection{Do SEnSo de JUSTIÇA AOS PRINCÍPIOS DE JUSTIÇA}

Como já foi falado na perspectiva ética, é às instituições que se aplica a virtude da justiça. Estas têm a missão de distribuir os bens e funções de maneira justa. Para Ricoeur, a percepção deontológica só conseguirá se estabelecer no campo institucional mediante um diálogo com a tradição contratualista, ou seja, com a ideia de que por meio de um contrato fictício, os indivíduos conseguem sair de seu estado primitivo de natureza atingindo o estado de direito.

Aqui, há a sobreposição do justo ao bom. A capacidade de escolha dos sujeitos em vista da vida boa é suprimida pela ideia de bem comum instaurada pelo contrato que, por sua vez, irá engendrar os princípios de justiça: "O contrato representa para as instituições, o que a autonomia 
representa para a moral, sendo que o primeiro estabelece as condições em que uma vontade boa, fruto da autonomia do homem, não tenha nenhuma restrição" (TURA, 2002, p. 180).

Ricoeur, analisando a obra de Rawls e percebendo sua proposição de um encontro entre uma perspectiva deontológica moral e uma corrente contratualista no horizonte das instituições, estabelece um diálogo com este pensador a partir do seguinte questionamento: "uma teoria contratualista será capaz de substituir pela abordagem procedimental toda e qualquer tentativa de fundamentar a justiça em algumas convicções prévias pertinentes ao bem do todo, o bem comum da politéia [...]?” (RICOEUR, 2008, p. 64). Rawls afirma decididamente que sim e para comprovar sua tese lança o conceito de equidade.

Primeiramente, é importante ressaltar que um acordo será equitativo se a situação de partida para todos for equitativa. A teoria da posição original juntamente com a alegoria do véu da ignorância que presume o desconhecimento dos sujeitos de seus respectivos lugares na sociedade, seus atributos, interesses e projetos comportam tal necessidade. Nesta situação, o que os indivíduos devem conhecer para estabelecerem os princípios da justiça?

Rawls afirma que os envolvidos devem compreender suficientemente a psicologia geral da humanidade no que se refere às paixões e motivações fundamentais, os bens sociais primários, sem os quais o exercício da liberdade seria uma reivindicação vazia, informações convenientes sobre os princípios de justiça que competem entre si, mas estas precisam ser as mesmas para todos a fim de que ninguém busque alguma espécie de vantagem e, por fim, o contrato será coercitivo na vida real, independentemente das circunstâncias. Nesta configuração todos se apresentam como iguais e, deste modo, segundo Rawls, todos escolherão a mesma argumentação.

Levando isso em conta e reforçando que a concepção rawlsiana de justiça está fundamentada no modo como as instituições de base distribuem direitos e deveres contando com a cooperação social, é possível apresentar os princípios indicados pelo filósofo. São dois:

Primeiro: cada pessoa tem um direito igual ao esquema mais extenso de liberdades básicas iguais compatíveis com um esquema similar de liberdades para os outros. 
Segundo: as desigualdades sociais e econômicas devem ser arranjadas de maneira que, ao mesmo tempo, (a) se possa esperar razoavelmente que elas sejam vantajosas para cada um e (b) elas estejam vinculadas a posições e funções abertas para todos (RAWLS apud PADILHA, 2012, p. 42).

Ademais, Ricoeur assinala a importante regra de prioridade entre os dois princípios denominada lexical. Deste modo, é imprescindível que o primeiro princípio seja anterior ao segundo uma vez que as liberdades iguais da cidadania são substanciais. Além disso, tal norma também se aplica entre as partes do segundo princípio, razão pela qual os menos favorecidos devem ser priorizados em relação aos outros parceiros.

O que levaria os indivíduos situados sob o véu da ignorância a acatar esses princípios? Rawls defende que a incerteza do sujeito com relação à sua posição original, ou seja, sua situação social e econômica, o levaria a decidir-se por esta configuração de contrato fundamentada na ideia do maximin: "o arranjo que maximizasse a parte mínima" (RICOEUR, 2008, p. 78). A sociedade, deste modo, estaria envolvida por um espírito de cooperação em busca de uma vida digna para todos.

Isto posto, Ricoeur volta a questionar: "Pode-se substituir uma fundamentação ética da justiça por uma concepção puramente procedimental?" (2008, p. 79-80). O filósofo, depois de uma longa análise, identifica um aspecto significativo na concepção do maximin de Rawls. Enquanto um argumento contra o utilitarismo, este estabeleceria que a pessoa humana em hipótese alguma deveria ser utilizada como meio, mesmo que isso possibilitasse o bem do todo, pois ela é um fim em si mesma. Tal tese retoma o segundo imperativo categórico e, consequentemente, a Regra de Ouro, o que torna "a regra do maximin como argumento tacitamente ético" (RICOEUR, 2008, p. 84).

Para o filósofo francês, este é o momento de construir uma mediação entre a tendência ética e a orientação puramente transcendental da teoria rawlsiana, ou seja, estruturar uma dialética entre teleologia e deontologia.

O caminho pode ser iluminado pela análise do conceito de convicções ponderadas apresentado por Rawls. Estas exprimem o consenso público sobre a noção de justiça e, por isso, podem apresentar incoerências no decorrer do tempo. Diante disso, segundo Rawls, é necessário que se faça uma comparação com os princípios universais da justiça como 
equidade na busca de uma coerência entre deontologia e teleologia. Isso apresentará a necessidade de um ajuste constante na aplicação da justiça que permeie o vaivém das convicções com os princípios tendo em vista a coerência com o contexto histórico da sociedade democrática em questão. Tal processo é denominado pelo autor de equilíbrio reflexivo.

Nesta trama, uma tensão aparece. Ao mesmo tempo em que Rawls anseia por uma teoria puramente procedimental da justiça, o argumento do maximin tem uma forte referência à Regra de Ouro e as convicções ponderadas são constituídas por uma grande bagagem ética: "nosso próprio senso de justiça e a ideia de uma deontologia precisam ser compreendidos em sua vinculação como resultado de uma longa tradição, advinda tanto da linhagem judaico-cristã quanto da herança greco-romana" (PADILHA, 2012, p. 49).

Além disso, como foi observado nestes últimos parágrafos e é reforçado por Ricoeur o senso de justiça deve ser submetido à crítica incessantemente a fim de que se consiga identificar preconceitos de viés ideológico ou outros princípios errôneos e maldosos para revisá-los ou erradicá-los: "Não podemos prescindir de uma avaliação crítica de nosso pretenso senso de justiça" (RICOEUR, 2008, p. 88). Caso contrário, práticas como escravidão, servidão ou torturas aconteceriam com intensidade muito maiores.

Isto posto, é possível concluir que, para Ricoeur, a deontologia não pode se desobrigar do recurso a um sentido ético de justiça, antes o supõe e exige, principalmente nas situações em que a moral se confronta com a complexidade da vida. Tendo isso em vista, prosseguir-se-á evidenciando a importância do estado de direito e da religião na construção da justiça.

\section{A IMPORTÂNCIA DO ESTADO LAICO E DA RELIGIÃO NA CONSTRUÇÃO DA JUSTIÇA}

Ricoeur é extremamente enfático ao estabelecer a importância das instituições na vida do ser humano:

Admitimos ali que só num meio institucional específico podem desenvolver-se as capacidades e disposições que distinguem o agir humano; o 
indivíduo, dizíamos então, só se torna humano sob a condição de certas instituições; e acrescentávamos: se for assim mesmo, a obrigação de servir essas instituições é condição para que o agente humano continue a desenvolver-se (2014, p. 293-294).

Em específico, o estado de direito enquanto instituição tem uma função significativa no estabelecimento da justiça, uma vez que, como já foi abordado, ele tem a responsabilidade de legislar a sociedade de modo a promover uma distribuição justa de bens, direitos e deveres. Para tal, a distribuição deve ser proporcional, isto é, de acordo com as necessidades de cada um. Isso legitimará a busca pela igualdade ou pelo menos colaborará na diminuição da desigualdade.

Essa prática, por sua vez, deve abranger todos os cidadãos, inclusive aqueles que não são vistos pelo si, buscando, deste modo, concretizar a intenção ética de viver bem juntos. O Estado de direito, portanto, "faz a passagem de laços de parentesco, de amizade ou de qualquer outra relação caracterizada como relação face-a-face, para a concretização da justiça de poucos para muitos, ou mais exatamente para todos" (DIAS; RAMPAZZO, 2015, p. 18).

Esta é uma concepção um tanto idealizada ou um parâmetro a ser seguido. No entanto, na contemporaneidade a realidade está bem distante desta configuração uma vez que o contexto atual é marcado pela corrupção, pelo egoísmo, pelo utilitarismo e pela usurpação do poder. A política, hoje, ao invés de se apresentar como a arte de administrar a cidade, identifica-se como um lugar de conflito por excelência.

Diante disso, Ricoeur interroga as práticas políticas retomando uma distinção feita por Hannah Arendt entre poder e dominação. O poder, como foi visto, é o querer viver e agir em comum numa comunidade histórica. A dominação, em contrapartida, já presume a desigualdade das relações e o tratamento do outro como coisa ou meio para alcançar os interesses próprios. À vista disso, aparece a violência como símbolo do Estado de direito: "a marca da força está em todas as cicatrizes deixadas pelo nascimento, na violência de todos os Estados que se tornaram Estados de direito" (RICOEUR, 2014, p. 296-297). E tal conjuntura se estende às relações interpessoais. Grupos rivais se enfrentam ferozmente e a paz é uma opção assustadora. Ademais, nos dias atuais, acredita-se 
que é preciso se impor e ganhar espaço sem pensar nas consequências dos atos cometidos.

Ricoeur é consciente de que numa democracia, num Estado de direito nunca haverá um consenso total que coloque fim aos conflitos, afinal, a pluralidade e o multiculturalismo são marcas deste sistema de governo. No entanto, a instituição deve prover regras de arbitragem que proporcione uma negociação diante de situações de divergência de modo que se dissipe o desejo de vingança e se instaure um sistema em que todos sejam tratados justamente, isto é, dando a cada um a sua parte. A reabilitação para quem precisa ser reabilitado e a reparação a quem foi caluniado ou violentado.

Quais seriam os fins de um bom governo? Eis um questionamento complexo e difícil de ser respondido. Ricoeur dá algumas pistas. Um bom governo auxiliará os governados a alcançarem aquilo que denominam vida realizada. Entretanto, o predicado bom utilizado carrega consigo uma pluralidade de sentidos, pois é visto de formas diferentes pelos inúmeros grupos de pessoas. Deste modo, será preciso escolher quais valores irão constituir esta espécie de governo e quais serão descartados tendo em vista, obviamente, o bem viver da comunidade. A phronesis aristotélica, ou seja, a sabedoria prática, será a guia nesta árdua missão e nas demais circunstâncias conflituosas como a que se segue.

A falta de fundamento para a escolha do governo é uma realidade extremamente atual e Ricoeur insere como fator para tal conjectura a crise de legitimação da democracia: "Fala-se com razão de crise de legitimação para designar a falta de fundamento que parece afetar a própria escolha de um governo do povo, para o povo e pelo povo" (2014, p. 300). Como atravessar este cenário?

Utilizando a sabedoria prática, os indivíduos irão recorrer ao passado para buscar respostas para o presente: "É constituindo a memória de todos os começos e recomeços, bem como de todas as tradições que sedimentaram suas bases, que o 'bom conselho' pode vencer o desafio da crise de legitimação" (RICOEUR, 2014, p. 302). É necessário, portanto, encontrar as tradições que dão oportunidade à tolerância e ao pluralismo por convicção interna. Sendo assim, a solicitude, a estima de si e a alteridade, conceitos tão caros a Ricoeur, estarão assegurados. 
Como se vê, "Ricoeur possui uma visão diferente dos pensadores que defendem que a política não possui uma racionalidade própria, sendo uma simples variável do econômico" (TURA, 2002, p. 90). Uma sociedade definida pela economia é marcada pela competição, pelas desigualdades e pela busca de sentido no cálculo, no trabalho, na pesquisa científica e tecnológica para aumentar a produção e o consumo e na felicidade privatizada. Estas circunstâncias talvez justifiquem a crise de legitimação e as dificuldades no âmbito de um governo autêntico.

Ricoeur propõe, deste modo, que se deve separar a política da economia de forma que a primeira caminhe numa perspectiva ética defendendo "um Estado democrático que garanta espaços para a liberdade, igualdade e não violência, onde os conflitos possam ser expressos e negociados, e os cidadãos sejam educados através da discussão e que todos tenham os seus direitos assegurados" (TURA, 2002, p. 94). Cumprindo tal missão, o Estado estará desempenhando seu papel de organizador da comunidade, ajudando-a a fazer história, a sobreviver e a viver bem conjuntamente, instaurando a justiça.

Ademais, cabe ao Estado de direito, "um serviço composto por uma burocracia íntegra, por juízes independentes, por parlamentares" (TURA, 2002, p. 94) fiscalizar a ação dos governantes, limitando seu poder em busca de uma reta administração. Aqui existe a intersecção entre a ética e a política e a economia estaria a serviço deste projeto comum.

A mudança, de fato, de um Estado de direito mundial que detém um monopólio de violência e injustiça para a globalização da não violência, está longe de ser alcançada. A cultura, de forma geral, propicia a formação de indivíduos violentos. No entanto, não se pode perder a esperança da construção de um Estado "que teria a função de criar condições de uma ação histórica sensata, através de escolas, das universidades, da cultura, da mídia, etc." (TURA, 2002, P. 96). Essa medida possibilitaria a formação de bons cidadãos e, consequentemente, bons governantes e juízes, que com o auxílio da estrutura estabelecida do Estado de direito e suas respectivas atribuições, conseguiriam edificar uma nação justa conforme as propriedades já estipuladas.

Por que, porém é importante que o Estado de direito tenha caráter de laicidade? Segundo Ricoeur, na política, a ética é dividida em duas partes, a moral de convicção e a moral de responsabilidade. A primeira 
está relacionada a valores próprios de determinados grupos da sociedade, por exemplo, as religiões. Os princípios podem ser utilizados como medidas para a construção da justiça. No entanto, quando se olha para o todo, a conciliação é improvável, uma vez que as diferenças em alguns casos são grandes. Por isso, a segunda espécie de moral estabelecerá imparcialmente o que é viável ser convencionado e fica estabelecido que os valores de uma religião, não podem ser utilizados como verdade universal e que o Estado precisa necessariamente ser laico.

É interessante notar, segundo Ricoeur, que mesmo diante da laicidade do Estado e da exigência de universalidade nos preceitos e normas, deve-se levar em conta a ética da convicção enraizada no justo das tradições religiosas. Deste modo, questiona-se: qual é a importância da religião na construção da justiça? Aqui Ricoeur propõe um diálogo entre filosofia e teologia a partir da Regra de Ouro recordando que esta expressa de maneira intuitiva o princípio moral mais fundamental, a saber, a concepção de pessoa como um fim em si mesma na perspectiva kantiana.

"Para ir diretamente ao essencial, diria que a religião pretende emanar toda experiência, entendida como experiência moral (mas não somente ela), na perspectiva da economia do dom"4(RICOEUR, 1993, p. 61, grifo do autor, tradução nossa). Aqui, os termos destacados merecem atenção. Quando se diz perspectiva, não se está buscando um fundamento, mas uma direção. Dizer dom é considerar uma doação originária que visa beneficiar todas as criaturas. Por fim, a economia demonstra que o dom se expressa numa realidade simbólica muito mais ampla que aquela da confissão e perdão dos pecados, mas alcança o plano salvífico.

Isto posto, este princípio possui raízes na bondade própria de todo ser humano enquanto criatura criada por Deus: "Deus viu tudo o que tinha feito: e era muito bom" (Gn 1, 31). Reconhecer esse elemento suscita no ser humano a vivência da humildade e da compaixão com relação a todas as outras criaturas. O erro por parte do outro não é mais motivo de escândalo, mas de clemência que, por sua vez, leva o

\footnotetext{
4 "Para ir directamente a lo essencial, diría que la religión pretende enmarcar toda experiencia, comprendida la experiencia moral (pero no sólo ella), en la perspectiva de la economía del don" (RICOEUR, 1993, p. 61).
} 
indivíduo a oferecer ajuda àquele que se equivocou. Perdão, serviço, humildade, solidariedade e reabilitação são aspectos significativos de quem entendeu esta condição.

Diante deste cenário, a Regra de Outro é renovada: "que novo sentido pode ter a Regra de Ouro se, não contente em basear-se na autonomia da liberdade, esta mesma fundação é colocada na perspectiva da economia do dom?"5 (RICOEUR, 1993, p. 62, tradução nossa). A Regra de Ouro era simplesmente enunciada como uma máxima conhecida no Sermão da Montanha: "Tudo aquilo, portanto, que quereis que os homens vos façam, fazei-o vós a eles, pois esta é a Lei e os Profetas" (Mt 7,12) ou mesmo no Sermão do Reino em Lucas 6,31.

É preciso, contudo, perscrutar o contexto em que ela foi apresentada a fim de interpretá-la corretamente. Deste modo, em Lucas 6, 27 se lê: "Eu, porém, vos digo, a vós que me escutais: Amai os vossos inimigos, fazei o bem aos que vos odeiam". Trata-se de um mandamento. Este parece aproximar a economia do dom ao plano ético ou, como diz Ricoeur supra-ético: "Encontra-se o ponto de articulação da economia do dom e da atividade legisladora da liberdade, no momento em que o dom engendra a obrigação" (1993, p. 62, tradução nossa).

Este mandamento novo evidencia a lógica da superabundância evangélica que se opõe à da equidade que governa a moral cotidiana advinda da Regra de Ouro. Enquanto a igualdade da segunda dá margem para o aditamento da lei de Talião, do olho por olho e dente por dente, o amor, com o caráter de reciprocidade, ordena a partilha sem esperar nada em troca: porque foi dado a você, dê você também.

No entanto, não se pode eliminar a Regra de Ouro. Segundo Ricoeur, isso tornaria a sociedade imoral, pois ela careceria do fundamento deontológico. Cabe, pois, uma dialética entre mandamento novo, religião, e tal regra a fim de que ambas se reinterpretem continuamente e conjuntamente de modo que a ética possa questionar a instituição em busca de uma vivência autêntica e contextual da justiça:

\footnotetext{
5 “¿qué nuevo sentido puede revestir la Regla de Oro si, no contentos con fundamentarla en la autonomia de la liberdad, se sitúa esta fundamentación misma en la perspectiva de la economia del don?" (RICOEUR, 1993, p. 62).

6 "Se encuentra en el punto de articulación de la economía del don y de la actividad legisladora de la libertad, en el punto en que el don engendra la obrigación" (RICOEUR, 1993, p. 62).
} 
Este trabalho de reinterpretação mútua não deixa o pensamento em repouso. Nunca acabam as reinterpretações. Porém, é também um trabalho prático, me atreveria a dizer. As aplicações desta dialética na vida cotidiana, no plano individual, no plano jurídico, no plano social e político, são inumeráveis e perfeitamente praticáveis. Diria que a incorporação tenaz, passo a passo, de um grau suplementar de compaixão e generosidade em todos os nossos códigos - código pena e código de justiça social -, constitui uma tarefa perfeitamente razoável, ainda que difícil e interminável ${ }^{7}$ (RICOEUR, 1993, p. 64-65, tradução nossa).

O amor cristão e a justiça, portanto, falam a mesma linguagem. Ambos buscam intervir na elaboração de comportamentos responsáveis. No entanto, cabe à religião o papel de ajudar os cidadãos a hierarquizarem seus valores de modo que possam fazer as escolhas corretas que, por sua vez, proporcionarão uma vida realizada com e para os outros. Ademais, ela deve assumir uma função crítica constante quanto à instituição denominada Estado de direito a fim de desorientá-la para, posteriormente, ajudá-la a se reorientar de acordo com a lógica do mandamento do amor, na qual sujeitos são vistos como fins em si mesmos e são valorizados e defendidos independentemente de suas ações. A reorientação, deste modo, tem a obrigação de superar uma visão utilitarista e violenta, abrindo o horizonte para uma perspectiva personalista, comunitarista e de estima e respeito a si mesmo e ao outro. Eis a importância da religião na construção da justiça.

\section{CONCLUSÃO}

Ricoeur se propôs a cumprir a exigente e complexa missão de elaborar uma composição unitária entre teleologia e deontologia, escolas que a tradição consagrou como opostas, e o fez com maestria. Ambas foram agregadas dialeticamente na tentativa de se aprofundar a noção

\footnotetext{
Este trabajo de reinterpretación mutua no deja al pensamiento en reposo. Nunca acaban las reinterpretaciones. Pero es también um trabajo práctico, me atrevería a decir. Las aplicaciones de esta dialéctica en la vida cotidiana, en el plano individual, en el plano jurídico, en el plano social y político, son innumerables y perfectamente practicables. Diría incluso que la incorporación tenaz, paso a paso, de un grado suplementario de compasión y de generosidad en todos nuestros códigos - código penal y código de justicia social -, constituye una tarea perfectamente razonable, aunque difícil e interminable (RICOEUR, 1993, p. 64-65).
} 
de justiça e chegou-se à conclusão de que o conceito na contemporaneidade sofreu um desvio tomando a forma de um conjunto de alternativas que uma sociedade opõe à violência em todas as suas formas, seja na linguagem (mentira) seja no corpo (sofrimento físico).

A violência imposta à outra pessoa suscita o desejo de vingança como forma tenaz de violência. Quebrar este ciclo de ódio representa uma grande oportunidade para a participação da religião, especificamente nesse projeto de tradição cristã, no resgate da interação entre amor e justiça, tal como o faz Paul Ricoeur. Pensando o amor para além de qualquer visão sentimentalista é possível apreendê-lo sob a ótica do dom de si mesmo ao outro. Assim sendo, o homem amoroso se torna responsável por si e pelo outro, agindo por convicção e com a liberdade que esta lhe garante, visando à igualdade entre todos os cidadãos e a realização da justiça.

Cabe às instituições, em especial ao Estado de direito e sua dimensão jurídica, ampliar esta conjuntura às suas estruturas. Implantando tal medida, violência e vingança cederão lugar para a paz, a justiça, o perdão e a reabilitação. O clima será de cooperação e comunitarismo de modo que todos abraçarão a causa do poder-em-comum em prol de uma vida realizada para todos. O personalismo ricoeuriano se apresentará como indispensável, fazendo da pessoa um fim em si mesma e sujeito capaz de com liberdade e responsabilidade agir justamente. A equidade exigirá a distribuição proporcional, dando a cada uma sua devida parte e, por fim, se alcançará uma vida boa com e para os outros em instituições justas.

É nesse horizonte que é possível pensar o papel da religião e do estado laico nas esferas da justiça a partir do diálogo entre a tradição cristã e a contemporânea sociedade secular.

\section{REFERÊNCIAS}

DAVID PELLAUER. Compreender Ricoeur. 2. ed. Petrópolis, RJ: Vozes, 2010.

DIAS, Mário José; RAMPAZZO (Org.). O conceito de justiça em Paul Ricoeur. Curitiba, PR: CRV, 2015. 
DIAS, Mário José; RAMPAZZO, Lino (Org.). Pessoa, comunidade e instituições na obra de E. Mounier e de P. Ricoeur. Campinas, SP: Editora Alínea, 2013.

LISBOA, Marcos José Alves. O conceito de identidade narrativa e a alteridade na obra de Paul Ricoeur: aproximações. Impulso. Piracicaba, v. 23, n. 56, p. 99-112, jan./abr. 2013.

PADILHA, Rafael Alves. Entre o bom e o legal: Ricoeur e a noção de justiça. Santa Maria, RS: UFSM (Universidade Federal de Santa Maria), 2012. (Dissertação de Mestrado em Filosofia).

RICOEUR, Paul. Amor y Justicia. Madri: Cararrós Editores, 1993.

RICOEUR, Paul. Leituras 1: Em torno ao político. São Paulo: Loyola, 1995.

RICOEUR, Paul. O justo 1: a justiça como regra moral e como instituição. São Paulo: WMF Martins Fontes, 2008.

RICOEUR, Paul. O si-mesmo como outro. São Paulo: Editora WMF Martins Fontes, 2014.

ROSSETTI, Ricardo. Justiça em Paul Ricoeur: uma hermenêutica do homem justo. São Paulo: LiberArs, 2015.

TURA, Marcelo Felix. Ética, política e utopia. Jaboticabal: Funep, 2002. 